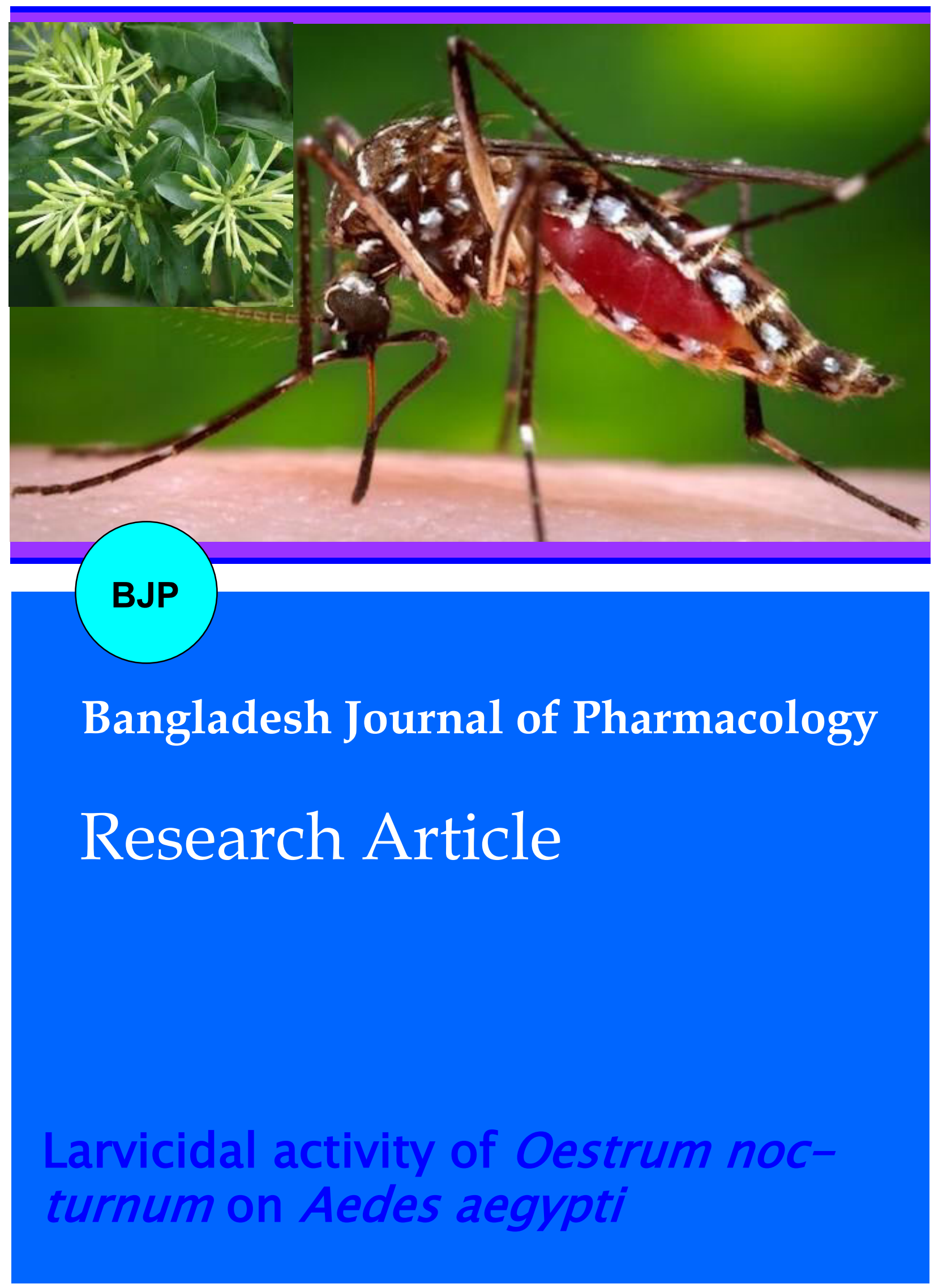


Abstracted/indexed in Academic Search Complete, Agroforestry Abstracts, Asia Journals Online, Bangladesh Journals Online, Biological Abstracts, BIOSIS Previews, CAB Abstracts, Current Abstracts, Directory of Open Access Journals, EMBASE/Excerpta Medica, Google Scholar, HINARI (WHO), International Pharmaceutical Abstracts, Open J-gate, Science Citation Index Expanded and Social Sciences Citation Index

\title{
Larvicidal activity of Oestrum nocturnum on Aedes aegypti
}

\author{
Chetan Jawale', Rambhau Kirdak² and Laxmikant Dama ${ }^{3}$ \\ ${ }^{1}$ Department of Zoology, HPT Arts \& RYK Science College, Nashik 422005, Maharashtra; ${ }^{2}$ Directorate of Higher \\ Education, Pune, Maharashtra; ${ }^{3}$ Department of Zoology D.B.F. Dayanand College of Arts and Science, Solapur \\ 413004, Maharashtra, India.
}

\begin{tabular}{|c|c|}
\hline \multicolumn{2}{|l|}{ Article Info } \\
\hline Received: & 5 April 2010 \\
\hline Accepted: & 9 May 2010 \\
\hline Available Online: & 2 June 2010 \\
\hline \multicolumn{2}{|c|}{ DOI: 10.3329/bjp.v5i1.4714 } \\
\hline \multicolumn{2}{|c|}{$\begin{array}{l}\text { Cite this article: } \\
\text { Jawale C, Kirdak R, Dama L. Larvicid- } \\
\text { al activity of Oestrum nocturnum on } \\
\text { Aedes aegypti. Bangladesh J Pharma- } \\
\text { col. 2010; 5: 39-40. }\end{array}$} \\
\hline
\end{tabular}

\begin{abstract}
Aedes aegypti is a vector parasite of the Dengue. New method to control the population of this insect is necessary. In the present work we evaluated the potential of extract from Cestrum nocturnum as larvicide. Methanol extract outstand as highly active larvicide, achieving 100\% larval mortality in 24 hours when tested in the concentration of $45 \mathrm{pg} / \mathrm{mL}$ (soxhlet) and $25 \mathrm{pg} / \mathrm{mL}$ (percolation). Any extract exhibiting significant larvicide activity was further fractioned and the fraction tested according to the WHO protocol. One fraction derived from methanol extract present remarkable $\mathrm{LC}_{100}$ at $12 \mathrm{pg} /$ $\mathrm{mL}$. LC50 of methanol extract and active fraction were found $14 \mathrm{pg} / \mathrm{mL}$ and 6 $\mathrm{pg} / \mathrm{mL}$ respectively. These fractions will be submitted to further fractions aiming to identify the molecules responsible for the larvicide activity.
\end{abstract}

\section{Introduction}

Dengue fever is considered as a serious public health problem in the world, mainly in tropical countries where the favorable environmental conditions are responsible for the proliferation of vectors Aedes aegypti. Among the arbovirus in India, distribution of all the dengue virus type is continuously expanding. Remarkably the reemergence of Chikungunya virus (CHIK) since 2005 is posing an additional concurrent diseases burden in the country including the Maharashtra. Both these virus are born by the mosquito A. aegypti (L) (Diptera:Culicidae) (Fulmali et al., 2008; Kumar et al., 2008). Periodic treatment with chemical insecticides and synthetic pyrethroids are done in breeding sits. Due to environmental concern on use of existing synthetic insecticides for vector control and further risk of development of widespread insecticides resistance in disease vector; interest on possible use of environment friendly natural products such as extracts of plants or plant parts increased for vector control. Sukumar et al. (1991) listed 346 species for 276 genera and 99 families which have been tested against mosquitoes for various effects such as toxicity, growth inhibition, ovipositional determinacy and repellent.
This list includes many species from Solanaceae family. Recently, Ghosh and Chandra (2006) and Ghosh et al. (2008) evaluated phytosteroidal compound of mature leaves of day jasmine Cestrum diurnum (Solanaceae:Solanales) against larvae of Culex quinquefasciatus (Diptera:Culicidae) and Anopheles stephensi. This study with plant extracts has been pointed as a promising alternative to combat this vector. In this work we evaluate the potential of extract from $C$. nocturnum as larvicide.

\section{Materials and Methods \\ Plant species}

C. nocturnum leaves were collected from gardens at Nashik city, Maharashtra State, India, in December 2008. Leaves were shed dried and powdered.

\section{Plant extraction}

The leaves were macerated and sequentially extracted with hexane, ethyl acetate and methanol using soxhlet and percolation extraction separately. The solvent were evaporated on rotary evaporator. Any extract exhibiting significant larvicide activities were further fractioned by filtration in silica get eluted with hexane-ethyl 


\begin{tabular}{|c|c|c|c|}
\hline \multicolumn{4}{|c|}{ Table I } \\
\hline \multicolumn{4}{|c|}{ Lethal concentration of $C$. nocturnum extracts } \\
\hline $\begin{array}{l}\text { Extraction } \\
\text { method }\end{array}$ & Extracts & $\begin{array}{c}\mathrm{LC100} \\
(\mathrm{pg} / \mathrm{mL})\end{array}$ & $\begin{array}{c}\text { Regression } \\
\text { equation }\end{array}$ \\
\hline \multirow[t]{3}{*}{ Soxhlet } & Hexane & $\mathrm{a}$ & $\mathrm{a}$ \\
\hline & Ethyl acetate & 300 & $\begin{array}{c}\mathrm{Y}=2.1180 \mathrm{X}+ \\
2.3457\end{array}$ \\
\hline & Methanol & 65 & $\begin{array}{c}\mathrm{Y}=1.9441 \mathrm{X}+ \\
3.3592\end{array}$ \\
\hline \multirow[t]{3}{*}{ Percolation } & Hexane & a & a \\
\hline & Ethyl acetate & 210 & $\begin{array}{c}\mathrm{Y}=1.7586 \mathrm{X}+ \\
2.0573\end{array}$ \\
\hline & Methanol & 35 & $\begin{array}{c}\mathrm{Y}=1.4832 \mathrm{X}+ \\
1.3753\end{array}$ \\
\hline
\end{tabular}

acetate mixture of increasing polarity, eight fraction were obtained.

\section{Bioassay}

Larvae were reared (Pelah et al., 2002) and third instars larvae were selected for bioassay. Larvae were transferred into the test solution with pasture pipette (20 larvae/solution). As a solvent, DMSO is used to soluble the extract in test water. Mortality of each test extract and fractions were determined after 24 hours exposure at $28^{\circ} \mathrm{C}$ following the protocol of WHO (1981). Mortality was corrected using Abbot formula (Finney, 1971) and the concentration at which $50 \%$ of the test population were dies (LC50) was determined by probit program (Finney, 1971).

\section{Results and Discussion}

Among the three extracts of C. nocturnum, percolation method extracts shows effective larvicidal activity over the soxhlet method (Table I). Methanol extract exhibit significant larvicidal activity causing $100 \%$ mortality in a concentration of $100 \mathrm{pg} / \mathrm{mL}$. This extract was further fractioned and the fractions obtained (CNM1-CNM6) were tested for larvicidal activity. The fraction CNM2, 3 and 4 presented the best results (Table II). CNM1, 5, 6 fraction didn't presented good activity in concentration lower than $350 \mathrm{pg} / \mathrm{mL}$ (result not shown). The LC50 of the methanol extract and its potent fraction (CNM3) is found $14( \pm 0.3113) \mathrm{pg} / \mathrm{mL}$ and $6( \pm 0.1532) \mathrm{pg} / \mathrm{mL}$ respectively (LC50 values are presented as average of four observations $\pm \mathrm{SE}$ ).

In all larvicidal assays, the methanol extract of $C$. nocturnum leaves extracted with percolation and its fractions presented higher larvicidal activity. Various authors have evaluated larvicidal activity of cestrum species on mosquitoes; where they found a steroidal bioactive compounds responsible for mosquitocidal activity (Ghosh and Chandra, 2006; Ghosh et al., 2008). Eight steroidal glycosides have been isolated from the leaves of C. nocturnum (Mimaki et al., 2002). Thus to

\begin{tabular}{|lccc|}
\hline \multicolumn{4}{|c|}{ Table II } \\
\hline \multicolumn{4}{|c|}{$\begin{array}{c}\text { Lethal concentration of fractionated methanol ex- } \\
\text { tract of } \text { C. } \text { nocturnum }\end{array}$} \\
\hline $\begin{array}{l}\text { Ex- } \\
\text { tracts }\end{array}$ & $\begin{array}{c}\text { Hexane:Ethyl } \\
\text { acetate }\end{array}$ & $\begin{array}{c}\mathrm{LC} 100 \\
(\mathrm{Pg} / \mathrm{mL})\end{array}$ & $\begin{array}{c}\text { Regression equa- } \\
\text { tion }\end{array}$ \\
\hline CNM2 & $1: 10$ & 60 & $\mathrm{Y}=2.0045 \mathrm{X}+1.0231$ \\
CNM3 & $1: 1$ & 12 & $\mathrm{Y}=1.4324 \mathrm{X}+2.1042$ \\
CNM4 & $10: 1$ & 75 & $\mathrm{Y}=2.2342 \mathrm{X}+1.1103$ \\
\hline
\end{tabular}

establish relevance of these steroidal compound with the mosquitocidal activity, fractions will be further fractionated to evaluate their potential to broad use and their possible toxic effect upon the other organism.

\section{Acknowledgement}

Authors would like to thank Prof. M. U. Patil, Department of Zoology and Dr. Babasaheb Ambedkar, Marathwada University, Aurangabad for providing basic training and necessary facilities to carry out the research work.

\section{References}

Finney DJ. Probit analysis. Cambridge (England), Cambridge University Press, 1971.

Fulmali PV, Walimbe A, Mahadev PV. Spread, establishment and prevalence of dengue vector Aedes aegypti (L.) in Konkan region, Maharashtra, India. Indian J Med Res. 2008; 127: 589601. PMid:18765879

Ghosh A, Chandra G. Biocontrol efficacy of Cestrum diurnum L. (Solanaceae: Solanales) against the larval forms of Anopheles stephensi. Nat Prod Res. 2006; 20: 371-79.

Ghosh A, Chowdhury N, Chandra G. Laboratory evaluation of phytosteroid compound of mature leaves of Day Jasmine (Solanaceae: Solanales) against larvae of Culex quinquefasciatus (Diptera:Culicidae) and nontarget organisms. Parasitol Res. 2008; 103: 271-77.

Kumar K, Chhabra M, Katyal R, Patnaik PK, Kukreti H, Rai A, Saxena VK, Mittal V, Lal S. Investigation of an outbreak of Chikungunya in Malegaon municipal areas of Nashik District, Maharashtra (India) and its control. J Vector Borne Dis. 2008; 45: 157-63.

Mimaki Y, Wantanabe K, Sakagami H, Sashida Y. Steroidal glycosides from the leaves of Cestrum nocturnum. J Nat Prod. 2002; 65: 1863-68.

Pelah D, Abramovich Z, Markus A, Wiesman Z. The use of commercial saponin from Quillaja saponaria bark as a natural larvicidal agent against Aedes aegypti and Culex pipiens. J Ethnopharmacol. 2002; 81: 407-09.

Sukumar K, Perich MJ, Boobar LR. Botanical derivatives in mosquito control: A review. J Am Mosq Control Assoc. 1991; 7: 210-37. PMid:1680152

World Heath Organization, Instructions for determining the susceptibility or resistance of mosquito larvae to insecticides. WHO/VBC. 1981; 81: 807-962.

Author Info
Chetan Jawale (Principal contact)
e-mail: csjawale@hotmail.com

